\title{
Illustration Images in Muslimah Visual Communication Da'wah Movement on Instagram
}

\author{
Rahina Nugrahani ${ }^{1, a)}$ Muhammad Zaffwan bin Idris ${ }^{2)}$ Arif Ardy Wibowo ${ }^{3)}$ \\ ${ }^{1}$ Universitas Negeri Semarang, Indonesia \\ a)author correspondence: rahina_dkv@mail.unnes.ac.id \\ ${ }^{2}$ Universiti Pendidikan Sultan Idris, Malaysia \\ ${ }^{3}$ Universitas Ahmad Dahlan, Yogyakarta, Indonesia
}

DOI: https://doi.org/10.18196/jkm.131049

Article Info

Article history:

Received 30 Jan 2021

Revised 05 Mar 2021

Accepted 10 Apr 2021

\section{ABSTRACT}

The rise of various $d a^{\prime}$ wah content on Instagram explains the emergence of Muslimah movement to deliver Islamic messages through social media. Through Instagram, the Muslimah community becomes an agent for transforming Islamic knowledge in carrying out $d a^{\prime}$ 'wah. This study aims to explain how the illustration artworks produced by the Muslimah community become visual communication media and provide their nuances in da'wah through Instagram. With a virtual ethnographic approach, this research is a qualitative study involving 15 illustrators who are members of the Hijabographic virtual community. This study reveals that the embodiment of the illustration artworks shows distinctive style and shape, which makes the Hijabographic community have its own positioning as a virtual community that produces illustration artworks for $d a$ 'wah content. As visual communication media, the illustration artworks created by Hijabographic community members contain iconic meanings that emphasize aesthetic principles. The creativity of Hijabographic community members in producing illustration artworks is not an individual phenomenon but a structured cultural system that is adaptive to the demands of technological development. Hijabographic community illustration artworks present a new way of performing $d a$ 'wah through virtual space.

Keywords: Hijabographic; instagram; virtual community; visual communication

\begin{abstract}
ABSTRAK
Maraknya berbagai konten Instagram bermuatan dakwah menjelaskan lahirnya sebuah pergerakan muslimah untuk menghadirkan media visual untuk mengkomunikasikan pesan-pesan ke-Islaman. Melalui Instagram, komunitas muslimah melibatkan diri sebagai agen transformasi pengetahuan Islam sebagai bagian dari pemenuhan kewajiban muslim dalam melakukan dakwah. Penelitian ini bertujuan untuk menjelaskan bagaimana karya gambar ilustrasi yang dihasilkan oleh komunitas muslimah dapat menjadi media komunikasi visual dan memberikan warna tersendiri dalam dakwah di media sosial Instagram. Menggunakan pendekatan etnografi virtual, penelitian ini merupakan penelitian kualitatif dengan melibatkan 15 ilustrator muslimah yang tergabung dalam komunitas virtual Hijabographic. Hasil penelitian mengungkap perwujudan karya ilustrasi menunjukkan corak, gaya, bentuk dan struktur yang khas, menjadikan komunitas Hijabographic memiliki positioning tersendiri sebagai sebuah komunitas virtual muslimah yang menghasilkan karya gambar ilustrasi bermuatan dakwah. Sebagai media komunikasi visual, karya ilustrasi yang dihasilkan oleh anggota komunitas Hijabographic mengandung makna ikonik yang tersirat dengan mengedepankan prinsip-prinsip estetis. Kreativitas anggota komunitas Hijabographic dalam menghasilkan karya gambar ilustrasi bukanlah sebuah fenomena individual, melainkan sebuah sistem budaya yang terstruktur namun adaptif mengikuti tuntutan perkembangan teknologi. Karya gambar ilustrasi komunitas Hijabographic menghadirkan pola baru dalam dakwah melalui ruang virtual.
\end{abstract}

Keywords: Hijabographic; instagram; komunikasi visual; virtual ommunity 


\section{INTRODUCTION}

Social media has encouraged the emergence of internet-based interactions, which create a new virtual-based social space. The development of communication technology, especially the discovery and use of social media, does not replace nor eliminate traditional face-to-face interaction patterns but instead complements existing interaction patterns (Collins \& Wellman, 2010; Jensen, Danziger, \& Venkatesh, 2007).

The emergence of interactive features on social media has brought about significant changes in media life in Indonesia (Nasrullah, 2012). Social media applications provide the capacity to produce and distribute information that encourages people to take an active role in consuming and producing content like professional content creators. Mainstream media industry players cannot withstand the rise of the virtual community era and are beginning to transform into news media that provide creative space for their audiences to actively produce information content (Kencana \& Meisyanti, 2020). In the past ten years, religious practices initiated by the younger generation, including Muslim women, through internet intermediaries have opened up space for anyone to have an opinion through social media (Slama \& Barendregt, 2018).

Muslimahs (Muslim women) take an active role in various da'wah activities that in previous decades were carried out by scholars and preachers who have backgrounds in Islamic educational institutions (Burhanudin, 2004). The terminology of da'wah then developed not only as lectures and recitations carried out in mosques. In the historical development of da'wah, it was noted that the message of da'wah was established as a dialogical product between the demands of the socio-cultural situation and became a factor giving meaning to teaching. Sometimes Islamic teachings interact with culture as a teaching message derived from a set of values contained in the culture. The dynamics of da'wah occur when Islamic teachings as da'wah material are processed and modified according to da'wah's practical needs. Da'wah messages are no longer limited to the text of the Koran and hadiths, but rather an understanding or interpretation resulting from the interaction between humans who live with thoughts and experiences with the sources of Islamic teachings. Moreover, the message of da'wah is compiled and formulated according to the purpose of the da'wah, which represents the mindset of the message maker (Fuadi, 2017).

The presence of a social world facilitated by internet technology produces a virtual interaction, creating what is known as a virtual community (Piliang, 2017). A virtual community is defined as a collection of individuals or business partners who interact around a common interest, whose interactions are partially supported and mediated by technology, and are guided by some protocol or norm (Blanchard, 2004; Porter, 2006). Porter states that there is basically no single virtual community typology that is widely supported. Researchers tend to categorize virtual communities based on one variable that is very important to their discipline or based on the studies they undertake. This is in line with what was stated by Komito $(1998 ; 2011)$ that the term community means many things to many people, and it would be difficult to find a definition of community that would be widely accepted.

Research on the existence of the Indonesian Hijabers Community conducted by Baulch \& Pramiyanti (2018) and revealed that Muslim women who are members of virtual communities generally use Instagram to disseminate Islamic religious values with the main target of more Muslim women from the upper-middle class. In other words, activities initiated through the Instagram social media platform are a more modern form of electronic da'wah. Hijabers' performance of the structure of femininity is veiled by two distinct spheres - a dynamic global digital culture and the changing field of Islamic communication. Hijabers are critical of conventional perceptions of religious values and norms, but they decide that some of them want to celebrate their religious side and their ability to play with their capacity to express their modesty and youth (Beta, 2014). This affects the way community members express and convey ideas in public spaces. They used the media strategically for their own purposes in a very different way from the prevalent use of the internet by other Muslims in the pre-digital era of information development as it is today (Nisa, 2013). The interactions that are built through virtual communities provide opportunities for Muslim women to expand their experiences.

In the era of the information revolution, digital media with computer and network technology at its core is the main form of information dissemination. Works that are categorized as visual communication design works become a medium for transmitting visual information that is very suitable for the characteristics of social media, which depend a lot on visual aesthetic aspects (Zhang, 2018). Islamic da'wah in its delivery needs to be packaged with a growing trend; therefore, unique 
methods are needed to be accessed by all groups (Wibowo, 2019). Likewise, such packaging should be applied to da'wah content through Instagram, which currently depends heavily on visual appearance. Digital natives access all the information needed in their life only through the screen in their hands. Visual stimulus is the most common way to support the successful delivery of information. Not only receiving information in visual presentation but also in its development, every individual in the digital era is slowly required to visually present and express all information. Social media platforms and online interactions, in general, are seen as playing an essential role in the process of constructing individual identities as adherents of the Muslim religion(Beta, 2014). In the concept of visual communication da'wah, skills are needed in the digital and multimedia fields. Thus, content creators must be directly involved in making material to develop and strengthen publications on social media (Wibowo 2020).

Visual communication media has a higher acceptance compared to other media. One example of visual communication media that is commonly used as a medium for da'wah is a poster containing messages from the Qur'an and Hadith (Ni'mah, 2016). Da'wah posters are currently widely published through Instagram social media. Toybah (2016), in their research, stated that the da'wah account on Instagram social media could be a very useful medium to become an intermediary for selfintrospection because, in each image, there is a message and motivation to do good.

The development of da'wah-charged Instagram content explains the emergence of a new group of da'wah content creators from among young people who are "computer literate" and become preachers of digital media. Through Instagram content, they try to become agents of the transformation of Islamic knowledge, which they believe are part of fulfilling Muslim obligations in carrying out da'wah. The da'wah content that they publish through Instagram refers to the sources they consider reliable. Nisa (2018), in her research, stated that the activist who created Instagram content with da'wah was not only an agent of their religious missionary community but also a key player in da'wah activities through Instagram. Nisa calls this phenomenon the preaching of Instagram. Photos, videos, electronic posters are the primary forms of communication on Instagram, which are also an attraction for young people, especially young women.

Based on some of the results of previous research, the discussion of illustrated images works as a visual communication medium in conveying da'wah on Instagram social media is still very limited. Thus, this research is essential to explain how the role of illustration images produced by the Muslim community can provide its color in preaching on Instagram social media. Specifically, this research aims to identify and analyze the embodiment of illustration drawings in terms of conceptual, operational, and aesthetic aspects that are unique and cannot be separated from the values of Islamic teachings.

\section{METHOD}

This study was designed using a virtual ethnographic approach. Hine (2000) argues that virtual ethnography is an online research method that adapts ethnographic methods and is generally used to study communities and cultures created through computer-mediated social interactions. Meanwhile, Steinmetz (2012) states that virtual ethnography is a development approach at present in line with the increasing use of online media in meeting cultural and social needs so that it has an impact on researchers who have to expand their approach to online interaction research. Furthermore, Driscoll \& Gregg (2010) states that if virtual ethnography tries to imitate what is done in classical ethnography, the real difference is the stability of identity, location, and depth of individual involvement in a community that is followed.

Boellstorff et al. (2012) said four steps were needed at the research design and preparation stage. First, compile a research question. Second, select the community or activity under study. Third, determine research locations that can be understood as a collection of actors, places, activities, and artifacts that can be physical, virtual, or a combination of both. Fourth, attend community activities that are held offline. This research, more specifically, involved 15 Muslim illustrators who are members of the Hijabographic virtual community, one of the virtual communities in Indonesia that have actively initiated visual da'wah activities on social media Instagram since 2013. This research was conducted over a period of three years, starting from 2017 to 2020. Data collection techniques were obtained through three activities, namely interviews, participatory observation, and document study. The research team conducted online and offline in-depth interviews involving founders and members of the Hijabographic community. Founders and community members are the primary data 
sources because it is possible to extract various information related to the vision and mission of the community, the activities held, and the patterns of interaction between members in the Hijabographic community. Participatory observation is carried out by being directly involved in online and offline activities organized by the Hijabographic community. The search for document data is used to determine the process of creating illustrations, the spirit of work, and how these works are used in visual communication da'wah on Instagram.

\section{RESULT AND DISCUSSION}

As one of the pioneer communities of da'wah on Instagram, the variety of visual communication media published by the Hijabographic community has reached more than 2,000 works. The most dominant works are illustrative drawings produced by Muslim illustrators who come from various cities in Indonesia. The themes raised in the drawings are diverse, ranging from Islamic knowledge, the environment, and the responses to actual issues. The illustrative works produced by the Hijabographic community can be appreciated through Hijabographic's official account on Instagram social media.
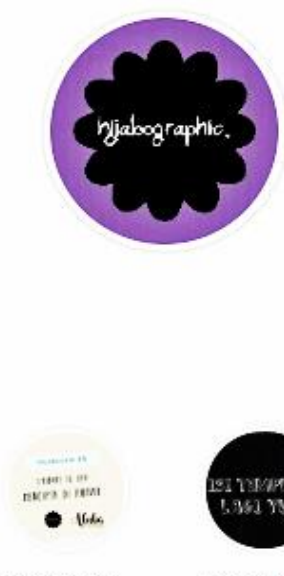

Hijabotalk\#...
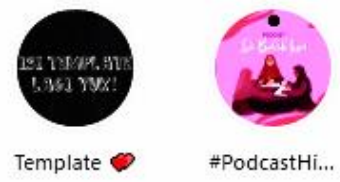

\#PodcastHi...

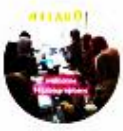

\#HBHHijab...

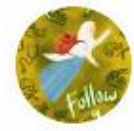

\#HijaboWa...

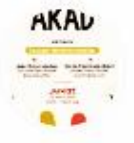

\#HijaboAsk...

Figure 1. Display of Hijabographic's official account on the Instagram platform Source: https://www.Instagram.com/hijabographic/ accessed on January 20, 2019

The Hijabographic community realizes the effectiveness of illustrated images as a visual communication medium for digital natives. Along with the times, drawing illustrations is not judged as visual literacy and technical quality but is a recognized scientific discipline and produces the best intellectual involvement to support learning material, problem-solving, and visual communication. Illustrative images can be applied to anything and are not solely driven by trends, and have the potential to reach a global community audience. Illustrative drawings, as submitted by Ijaz (2018), play an important role in the world of digital communication. Illustrative images can influence humans when informing messages, directing humans to make purchasing decisions, and persuading humans to take certain actions (Male, 2007). This confirms that illustrative drawings have long been an effective visual communication medium and can be applied in various communication patterns.

A good illustration can successfully and creatively produce a process of transferring specific messages from the communicator to the targeted audience. There are at least five contextual domains in illustration artwork: information, commentary, narrative fiction, persuasion, and identity. Likely, any idea/message (brief) initiated through illustration work will accommodate at least one of these domains, although it is also possible to accommodate more than one domain (Male, 2007; Sharma, 2013).

The following shows 15 illustrative images created by members of the Hijabographic community, categorized based on three themes: humans, flora, and October. 
Table 1. Illustrative images produced by the Hijabographic community

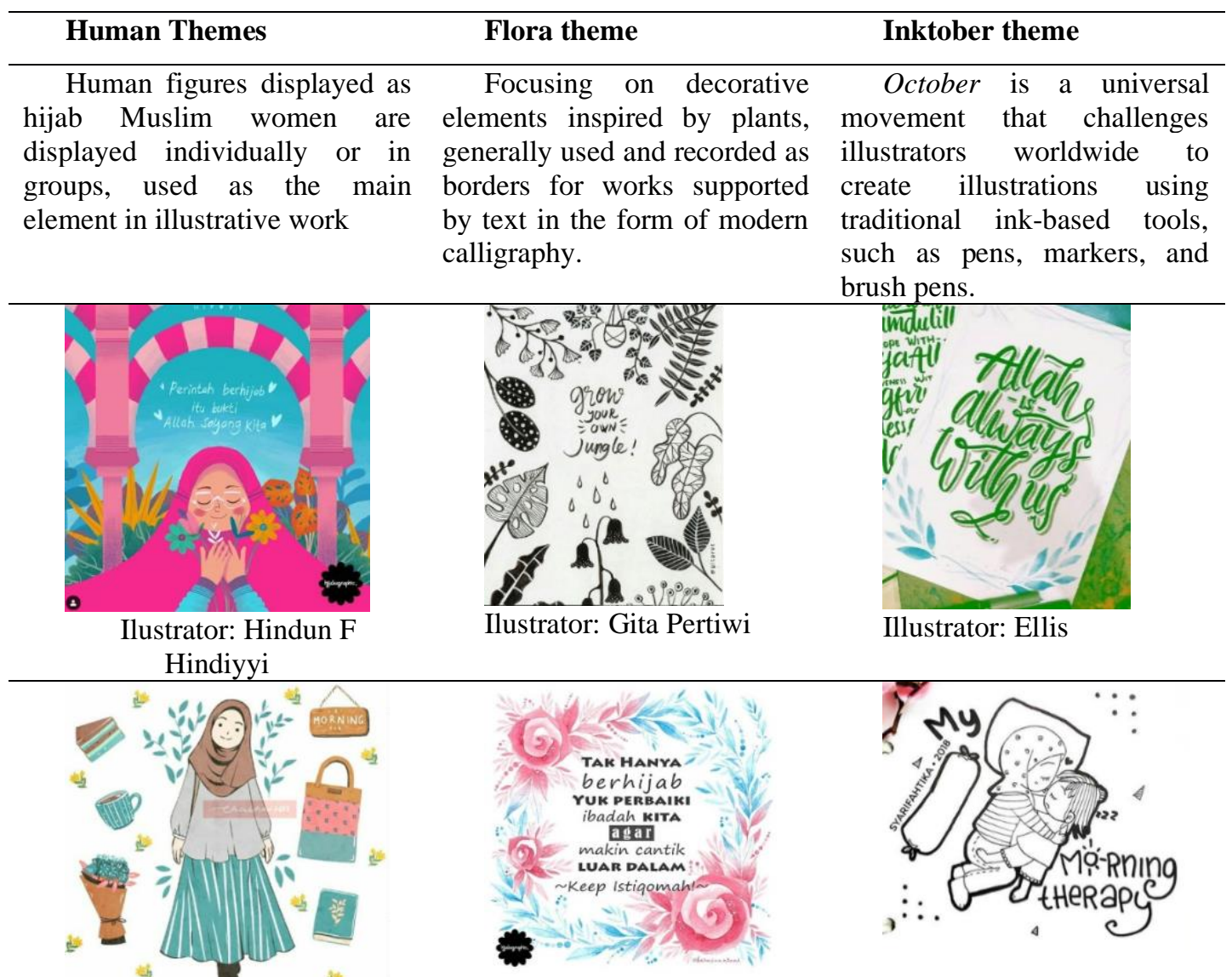

Ilustrator : Chacha Faiza

Ilustrator: Hermina Utami

Ilustrator: Syarifah Tika

Putri

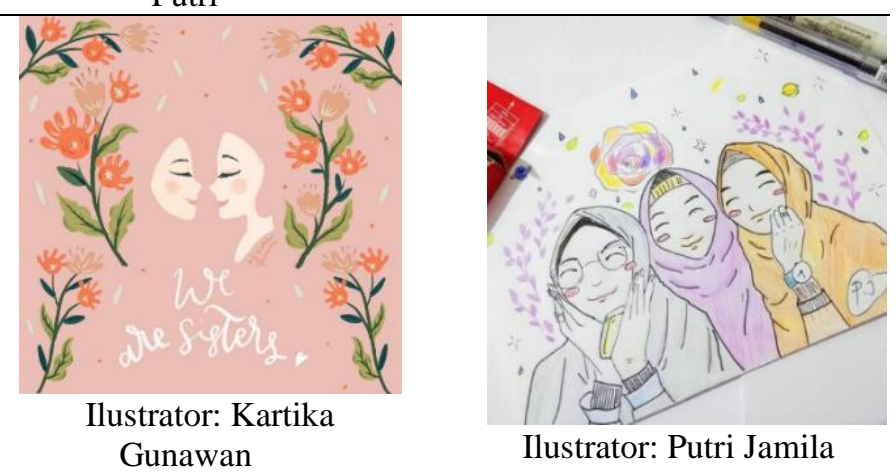

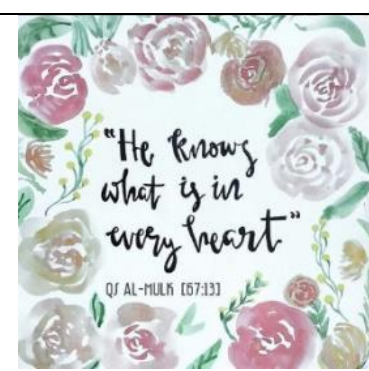

Ilustrator: Linahriyanti

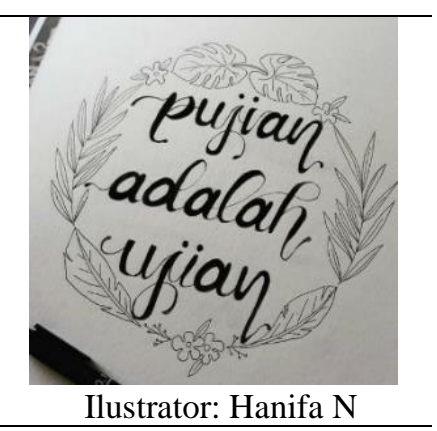




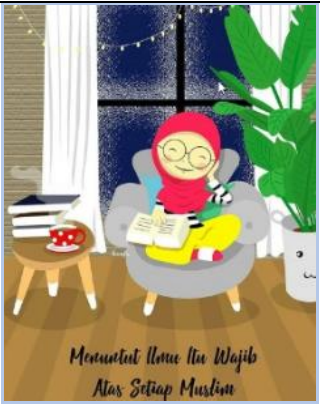

Ilustrator: Hanifa Nurdiana

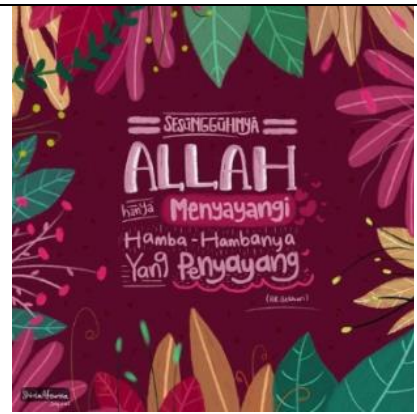

Ilustrator: Shinta Ayu

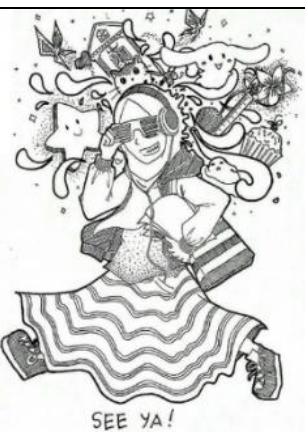

Ilustrator: Sarah Syarifah

To be able to formulate the form, style, and structure of the fifteen illustrative images produced by members of the Hijabographic community and to become respondents in this article, a visual analysis was carried out. The visual analysis is related to conceptual elements, operational elements, and aesthetic elements that made the Hijabographic community illustration image work as a visual communication medium in delivering da'wah on Instagram. Visual analysis, in this case, is needed to reveal the relationship between verbal and non-verbal messages conveyed by members of the Hijabographic community in delivering da'wah on social media on Instagram.

\section{Visual Analysis of Illustration Images as Communication Media}

The conceptual aspect in producing a visual artwork is related to inner reality and sensory experiences obtained from environmental experiences. Art was created on the belief that sensory experience is the best way to know, think and feel. The aspects that form the basis of conception can be seen as part of expressive behavior.

Expressive action is a projection of expressive impulses through an expressive medium to know the subject, namely a means for an individual to know their feelings. Through the visual analysis carried out on 15 illustrative works with various themes, approaches, and techniques, it can be seen that these works have similarities in conceptual terms. In Hijabographic illustrative works, it can be seen that the basis of work for community members is the beliefs they have.

The awareness to preach (deliver religious value) becomes the basis for community members to work and convey messages of kindness in their posts on Instagram social media. The spirit of da'wah is the dominant concept in every work. This statement is emphasized by the founder of the Hijabographic community, that the purpose of creating illustrations for community members is indeed intended to convey messages of kindness.

Drawing living creatures in Islam is a matter of debate among scholars. Some Muslim scholars forbid drawing the images of living things in which there are spirits such as humans and animals and birds on the surface of paper, skin, clothing, utensils, jewelry, money, or others based their opinion on the following hadith narrated by Bukhari Muslim:

Narrated in the hadith narrated by Ibn Umar radhiallahu'anhuma, Rasulullah SAW has said:

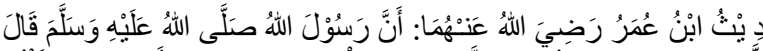

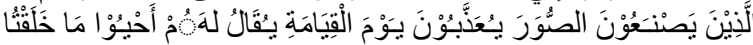

Meaning: Narrated from Ibn Umar radhiyallahu'anhuma, he has said: Verily the Messenger of Allah -peace and prayer of Allah be upon him- said: Those who make or paint pictures will be tortured on the Day of Resurrection. They will be ordered: Live what you have created. (Narrated by Bukari Muslim)

Interpreting this hadith, the Ulama argue that drawing Allah's creatures, making statues to be worshiped, or creating anything that has the effect of reducing the level of faith and even eliminating the greatness of Allah, will get an excruciating torment in the hereafter. This prohibition is based on the tendency of humans who are often excessive in admiring their own creations or those of fellow humans.

The above hadith forbids Muslims to draw anything with a spirit/soul, and the law does not allow it to be absolute. Meanwhile, images that do not have a spirit, such as trees, sea, mountains, and the 
like can be drawn, as said by Ibn Abbas radhiallahu'anhuma. In understanding the hadith which reads "Live what you are making" as well as the hadith "he will be required to breathe the spirit into the image on the Day of Judgment, and he will not be able to do it", there is a difference of opinion among the scholars. Various narrations show that there were among the Sahabat Rasul who denied Ibn Abbas's statement, but there were also Sahabat who agreed with Ibn Abbas's opinion.

The Hijabographic community understands the existence of ijma' among scholars concerning this opinion. Not all scholars forbid drawing or drawing products featuring living things. The Hijabographic community rests on the belief that it is permissible to draw in Islam based on the opinion expressed by Syekh Yusuf Qardhawi, who divides the law of drawing based on purpose, provided that the image is placed and how the process is made. If the image is in the form of something that is made an offering other than Allah, then the law is haram. Included in the prohibition are images of cultured creatures. However, if the painted image is a drawing of an animated creature but not to be worshiped or cultured, the law does not extend to the degree of haram. According to Sheikh Qaradawi, the highest law is makruh (Muftisany \& Sasongko, 2016). Nowadays, illustrative drawings and graphic design works are widely used as an exciting medium of preaching. Visual communication works are readily accepted and understood by Muslims and far from potential shirk. Therefore, the law of visual-based works such as illustrated images becomes permissible when we refer to the rules of Ushul Fiqih, that making illustrations and other graphic design works intended for proselytizing is permissible (Zain, 2018).

Based on their belief in the opinion of Sheikh Yusuf Qardhawi, the Hijabographic community made an agreement and understanding that the illustrated artwork can be of merit if it is intended for the benefit of syi'ar. The concept of illustrated images as a medium for preaching Islam is the main foundation of the Hijabographic community in their work. Riza Sativianti, as one of the founders of the community, in an interview held in February 2018, said that there are a set of rules for work set by the Hijabographic community.

Based on the information from the founder of the Hijabographic community, it can be summarized that a set of rules for publishing illustrated images in the Hijabographic community are as follows:

1. Illustrative work must be following the sharia rules, such as: not presenting a female figure/displaying the aurat, avoiding images that are too realistic, and not displaying images that invite lust.

2. The illustration work is intended to help convey Islamic messages, and the message conveyed is a message that can be justified.

The community founder admitted that preaching through Instagram, as adopted by Hijabograhic, has opened a public space that allows everyone to provide feedback directly if there are things deemed inappropriate. This is in line with Mahanani (2014) that social media facilitates interaction between users and opens a space for discussion in a virtual space. Riza said that once the Hijabographic community was reminded by a party who said that posting of illustrated images published on Instagram accompanied by a caption containing certain hadiths was considered less relevant and inaccurate because the community displayed hadiths that were dho'if (weak). Since then, according to Riza, the Hijabographic community is more selective in carrying out the filter process to determine whether a work by the Hijabographic community members is appropriate or not to be published. This is an important key to the continuation of creative da'wah activities in the Hijabographic community (Nugrahani et al., 2019). Illustrative images produced by community members are created and used as a communication medium to build interactions between the community and target audiences.

In terms of operational aspects, Hijabographic community members produce illustrative images using various methods of work. Broadly speaking, illustrative work produced by Hijabographic community members is divided into two categories, namely illustration drawings produced by manual/conventional methods and illustration drawings produced by computerized methods. 


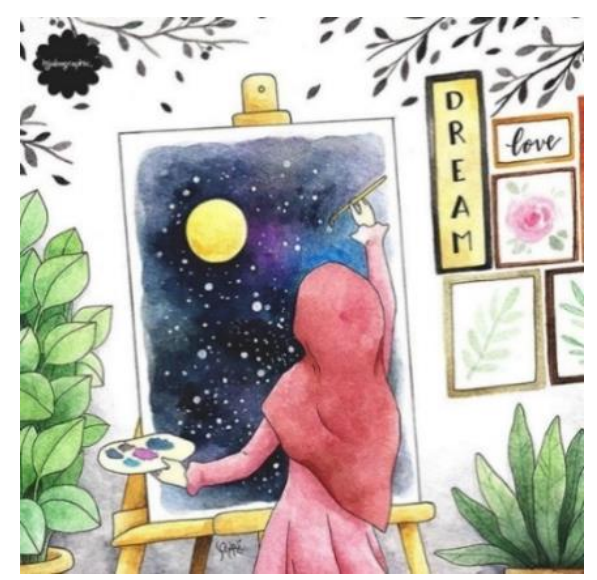

Figure 2. Examples of illustrative drawings produced using conventional methods, source: Instagram.com/hijabographic/ accessed on January 20, 2019 by Putri Hermina Utami (@ hermina.utami)

The Hijabographic community provides space for community members to produce illustrative work with various methods and approaches. Based on the results of interviews conducted by researchers with community members, it can be seen that the work of community members that the Hijabograhic admin has published on Instagram social media has often become an inspiration for fellow members to be able to share illustration drawing techniques that have never been studied. Some members of the Hijabographic community who are actively working, such as Putri Hermina Utami and Chacha Faiza, often record the process of creating their illustrated images to become references for other community members.

This is in line with what was stated by one of the Muslim women illustrators, Hanifa (31 years), who is a contributor to illustrative work in the Hijabographic community. Based on Hanifa's statement, Hijabographic is a trigger for her to produce illustrative drawings with the latest techniques and styles. The illustrative works produced by fellow Muslim women in the community are an inspiration and give their own color to Hanifa's works.

"I think Hijabographic can give us insight if the quality of Muslim women has come so far, they are already good at work. When I saw the works on the Hijabographic account, I felt motivated to make them, too, so an idea emerged to make illustrations with the same theme or different themes. The problem is good, really. Those who previously followed Hijabographic were able to follow Muslim creators who were really productive drawing them. Sometimes I like to follow along and watch their time-lapse drawing process. You can also learn from their process. "(Research team interview with Hanifa Nurdiana, March 14, 2020)

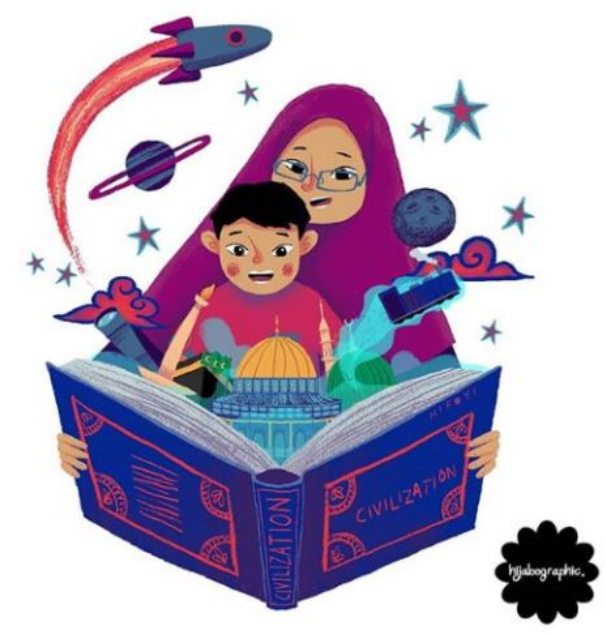

Figure 3. Examples of illustrative drawings generated using computerized methods, source: Instagram.com/hijabographic/ accessed on March 13, 2019 by Hindun (@ hifoyi) 
The operational aspect of producing illustrative work in the Hijabographic community is oriented towards the use of technology. This is because the platform used to publish works is a multimodal platform. A two-dimensional-based visual artwork and the ability to process good narratives and messages through captions are needed to grab the audience's attention. Hijabographic community members also have a good understanding of the Instagram algorithm to determine strategies so that Hijabographic posts get a broad audience reach and the proper segmentation. In general, the Hijabographic creative team knows how the most relevant tips and tricks are to maintain audience loyalty to Hijabographic's official account. By setting the frequency and time of publication of works, actions that need to be taken after uploading works of community members, determining keywords and hashtags for each publication, and so on. Thus, the operational aspects which are essential to be considered are not only the media at work but also the management of works at the time of publication.

From the aspect of aesthetics, the embodiment of illustrative works shows a distinctive style, shape, and structure, making the Hijabographic community a distinct positioning as a virtual Muslim community that produces illustration works with da'wah content. To sum up, community members' trends of shapes, colors, and patterns in producing illustrative drawings are presented in the following table.

Table 2. Shapes, colors, and patterns that appear in Hijabographic illustration drawings

\begin{tabular}{|c|c|c|}
\hline Form & Color & Pattern \\
\hline $\begin{array}{l}\text { In general, the shapes shown in } \\
\text { the illustration work are made with } \\
\text { a combination of curved lines and } \\
\text { organic looks that can be seen on } \\
\text { the figures of Muslim women, } \\
\text { flora, as well as types of } \\
\text { typography. This gives the } \\
\text { impression that the illustration } \\
\text { works produced by community } \\
\text { members look feminine. Muslim } \\
\text { figures are always depicted } \\
\text { wearing hijab and clothes that } \\
\text { cover their aurat, in a simple }\end{array}$ & $\begin{array}{l}\text { The colors used in the } \\
\text { illustration work produced by } \\
\text { Hijabographic community } \\
\text { members use bright colors and } \\
\text { soft colors with low-intensity } \\
\text { values, such as pink, light } \\
\text { purple, light blue, light } \\
\text { yellow, cream, gray, tosca, } \\
\text { and light green. In some } \\
\text { illustrations, the most widely } \\
\text { used combination is pink and } \\
\text { light blue. }\end{array}$ & $\begin{array}{l}\text { The layout used by } \\
\text { community members } \\
\text { generally uses symmetrical } \\
\text { balance, with parts on the left- } \\
\text { right, top-bottom arranged in } \\
\text { a balanced and proportionate } \\
\text { manner. Circular symmetrical } \\
\text { balance can also be seen in } \\
\text { several illustrative works } \\
\text { featuring Islamic quotes or } \\
\text { quotes. The readability flow } \\
\text { used is top to bottom, from } \\
\text { left to right. }\end{array}$ \\
\hline
\end{tabular}
cartoon style that is not shown in detail.

Hijabographic responds and takes advantage of the potential and knowledge possessed by Hijabographic community members to create illustrations using manual and digital techniques and utilize social media to publish them. These publications are not only intended for the sake of existence. More than that, Hijabographic's main objective is to increase awareness of its target audience to become devout and solih (pious) Muslim women.

\section{Illustration Drawing Works as a Visual Communication Media}

Illustrative images used by the Hijabographic community on Instagram social media to carry out da'wah activities can be categorized as multimodal texts. The characteristics of the messages mainly conveyed contain verbal and visual elements whose existence cannot be analyzed only by a linguistic approach but also by visual analysis (image analysis tool/image reading), which complements each other in order to produce a comprehensive understanding of the meaning (Holsanova, 2012).

Illustration as a visual communication medium in conveying da'wah on Instagram social media is the ability of Muslim women to understand the world through various points of view. Empathy and environmental analysis skills are necessary for an illustrator to develop sensitivity in understanding socio-cultural conditions so that they can communicate messages and ideas in a way that is considered the most appropriate to the characteristics of their target audience. Muslim illustrators who are members of the Hijabographic community realize that visual-based communication media are considered one of the most effective tools for young people who are familiar with social media such 
as Instagram. As a visual content-sharing service provider, Instagram is one of the social media with the most users, which is as many as 300 million users worldwide. In addition to photography, Instagram is one of the most widely used platforms for sharing illustration image work, which is generally used as a supporting communication medium that complements specific written texts, aiming to help audiences understand messages more quickly.

Hijabographic uses these illustrated images as a visual-based communication medium that carries Islamic messages. The illustrations produced by Hijabographic are inspired mainly by the daily life activities of Muslim women. Some are interpretive works produced to create a particular nuance, and each work creates new meanings that revolve around cyberculture, opens up spaces for interaction between community members and followers of Hijabographic on Instagram social media. This is in line with what was conveyed by Fahmy, S., Bock, \& Wayne (2014) that visual images represent reality, create causal relationships and encourage interaction.

Instagram creates a trend in the use of visual-based social communication media, and the Hijabographic community has the ability to build Instagram user engagement to carry out creative activities and appreciate the illustrative artwork produced by its members. Like other social media platforms, Instagram is a multimodal mode of communication. The communication referred to in this context is not only interpreted as an event of delivering a message from the sender to the recipient, but also an attempt to offer the meaning of the interpreter (illustrator) to the audience. Every illustration work produced by the Hijbaographic community is always accompanied by a caption/information that confirms the message conveyed by the illustrator through their illustrative work. The ability to produce high-quality imaginary images both visually, technically, and in message content by utilizing various features provided by Instagram is a strategic Hijabographic activity to deliver da'wah with a technology-based approach.

As a work that is published online and can be accessed openly, the work produced by the Hijabograhic community is public art. The existence of illustrated images produced by the Hijabographic community can be called a collaborative intervention (Abad \& Palacios, 2008) which changes the public space to develop knowledge and skills to explore new things, and Hijabograhic facilitates this open space in a virtual public space.

The existence of illustrated drawings as creative products produced by the Hijabographic community is an aesthetic-expressive symbol that expresses Islamic knowledge, beliefs, and values held by community members. Therefore, the aesthetic aspect that appears in the illustrated images by members of the Hijabographic community is different from other virtual communities. This is because the process of acting and behaving in the arts is always influenced, directed, and controlled by everything that is considered as beliefs. It is the belief to use illustrated images as a medium to convey Islamic values to fellow Muslims. In the Hijabographic community, illustrated drawings are a model for conveying da'wah in a subtle way (soft da'wah), whereas, as conveyed by Nisa (2018), the creativity and enthusiasm of Instagram preaching content creators stem from their strong belief that a picture is worth a thousand words. This positions the Hijabographic virtual community, which is active in producing creative content in the form of illustrated images, as social media influencers and allows them to carry out soft da'wah with the primary target audience of Muslim women. This soft da'wah model is used selectively by members of the Hijabographic community to produce illustrative drawings that does not only function as a digital visual artwork but also as a medium to communicate, connect the knowledge, instill Islamic values, and as an attitude or actions aimed at fulfilling their aesthetic needs.

\section{CONCLUSION}

Illustration images published through Instagram social media have become visual text, where technology plays an important role in shaping the relationship between visual text and reality. Visual representations present reality in the form of representational images, which manifest into a coded form of communication. As a visual communication medium, the illustration works produced by Hijabographic community members contain iconic meanings that are implied by prioritizing aesthetic principles. Each illustration work that is produced accentuates a distinctive feminine side, which is manifested through the shapes, structures, and colors used by each illustrator to confirm the identity of their work as a work produced by Muslim women. Through illustrative images published on Instagram, they can maximize their role in conveying Islamic messages with media that are easily 
accepted and enjoyed by the broader target audience of Muslim women of various ages and backgrounds. This convenience is occurrent due to the characteristics of social media as a da'wah platform that can anticipate the limitations of distance and time.

The creativity of Hijabographic community members in producing illustrated drawings is not an individual phenomenon. Rather, it is a cultural system that is structured but adaptive to keep up with the demands of technological developments. As a virtual community, Hijabographic acts as an agent that mobilizes community members to be able to generate new ideas, systems, and products that can be used to convey messages containing da'wah on social media in the form of illustrated images. Hijabographic community members are creative individuals who have succeeded in using symbolic sources in the domains of art, visual communication, and information technology to create works containing moral messages and Islamic values.

\section{REFERENCES}

Abad, J., \& Palacios, A. (2008). Escribir el Lugar: Collaborative Projects. Public Spaces. International Journal of Education Through Art, 4(2).

Baulch, E., \& Pramiyanti, A. (2018). Hijabers on Instagram: Using Visual Social Media to Construct the Ideal Muslim Woman. Social Media + Society, 1-15. https://doi.org/10.1177/2056305118800308

Beta, A. R. (2014). Hijaber: How Young Urban Muslim Women Redefine Themselves in Indonesia. The International Communication Gazette, 76(4-5), 377-389.

Blanchard, A. (2004). Blogs as virtual communities: Identifying a sense of community in the Julie/Julia project. Into the Blogosphere Rhetoric Community and Culture of Weblogs. Retrieved from http://blog.lib.umn.edu/blogosphere/blogs_as_virtual.html

Boellstorff, T., Nardi, B., Pearce, C., \& Taylor, T. L. (2012). Ethnography and Virtual Worlds. New Jersey: Princeton University Press Princeton and Oxford.

Burhanudin, J. (2004). The Fragmentation of Religious Authority: Islamic Print Media in Early 20thCentury Indonesia. Studia Islamika, 11(1), 23-62.

Collins, J., \& Wellman, B. (2010). Small Town in the Internet Society: Chapleau is No Longer an Island. American Behavioral Scientist, 53(9), 1344-1366.

Driscoll, C., \& Gregg, M. (2010). My profile: The ethics of virtual ethnography. Emotion, Space and Society, 3(1), 15-20. https://doi.org/10.1016/j.emospa.2010.01.012

Fahmy, S., Bock, M. A., \& Wayne, W. (2014). Visual communication theory and research. A mass communication perspective. New York: Palgrave Macmillan.

Fuadi, M. H. (2017). Pesan Dakwah Hasan Al-Banna dalam Buku Majmuatur Rasail. Ilmu Dakwah: Academic Journal for Homiletic Studies, 11(2), 325-340. https://doi.org/10.15575/idajhs.v11i2.2418

Hine, C. (2000). Virtual Ethnography. London: Sage.

Holsanova, J. (2012). New Methods for Studying Visual Communication and Multimodal Integration. Visual Communication, 11(3), 251-257. https://doi.org/https://doi.org/10.1177/1470412912446558

Ijaz, N. (2018). Art of Visual Communication, Evolution and its Impact. Indian Journal of Public Health Research and Development, 9(12), 1725-1728. https://doi.org/10.5958/09765506.2018.02238.6

Jensen, M., Danziger, J., \& Venkatesh, A. (2007). Civil Society and Cyber Society: The Role of the Internet in Community Associations and Democratic Politics. Information Society, 1(23), 39-50.

Kencana, W. H., \& Meisyanti, M. (2020). The Implementation of Mass Media Digital Platform in Indonesia. Komunikator, 12(2), 90-105.

Komito, L. (1998). The Net as a Foraging Society: Flexible Communities. The Information Society, 14:2, 97-106. https://doi.org/10.1080/019722498128908

Komito, L. (2011). Social Media and Migration: Virtual Community 2.0. Journal of the American Society for Information Science and Technology, 62(6), 1075-1086. https://doi.org/10.1002/asi.21517

Mahanani, P. A. R. (2014). Media Sosial dan Gaya Komunikasi. Komunikator, 6(1), 59-69.

Male, A. (2007). Illustration: A Theoreticl and Contextual Perspective. Lausanne: AVA Publishing SA. 
Muftisany, H., \& Sasongko, A. (2016). Soal Menggambar dan Fotografi, ini Pandangan Ulama. Republika.Co.Id. Retrieved from https://www.republika.co.id/berita/duniaislam/fatwa/16/08/03/obatcq313-soal-menggambar-dan-fotografi-ini-pandangan-ulama

Nasrullah, R. (2012). Internet dan Ruang Publik Virtual, Sebuah Refleksi atas Teori Ruang Publik Habermas. Komunikator, 4(1), 26-35.

Ni'mah, N. (2016). Dakwah Komunikasi Visual. Islamic Communication Journal, 1(1), 104-120. https://doi.org/10.21580/icj.2016.1.1.1241

Nisa, E. F. (2013). The internet subculture of Indonesian face-veiled women. International Journal of Cultural Studies, 16(3), 241-255. https://doi.org/10.1177/1367877912474534

Nisa, E. F. (2018). Creative and Lucrative Da'wa_ The Visual Culture of Instagram amongst Female Muslim Youth in Indonesia.pdf. Asiascape: Digital Asia, 5, 68-99. https://doi.org/10.1163/22142312-12340085

Nugrahani, R., Rohidi, T. Triyanto, \& Syarif, M. . (2019). Illustration Artworks of Hijabographic: Visual Expressions in Virtual Learning Community. In Proceedings of the 5th International Conference on Science, Education and Technology (pp. 1-8). EAI. https://doi.org/http://dx.doi.org/10.4108/eai.29-6-2019.2290501

Piliang, Y. A. (2017). Dunia Yang Berlari. (Taufiqurrahman, Ed.) (Second Edi). Yogyakarta: Aurora.

Porter, C. E. (2006). A Typology of Virtual Communities: A Multi-Disciplinary Foundation for Future Research. Journal of Computer-Mediated Communication, 10(1), 01-30. https://doi.org/10.1111/j.1083-6101.2004.tb00228.x

Sharma, P. B. (2013). Painting: A tool of Non-Verbal Communication. Language in India, 13, 312318.

Slama, M., \& Barendregt, B. (2018). Online Publics in Muslim Southeast Asia: In Between Religious Politics and Popular Pious Practices, 5, 3-31. https://doi.org/10.1163/22142312-12340090

Steinmetz, K. F. (2012). Message received: Virtual ethnography in online message boards. International Journal of Qualitative Methods, 11(1), 26-39. https://doi.org/10.1177/160940691201100103

Toybah, N. R. (2016). Dakwah Komunikasi Visual Melalui Instagram Akun @HADITSKU. Alhiwar Jurnal Ilmu Dan Teknik Dakwah, 4(7), 118-131.

Wibowo, Adi. (2019). PENGGUNAAN MEDIA SOSIAL SEBAGAI TREND MEDIA DAKWAH PENDIDIKAN ISLAM DI ERA DIGITAL. Jurnal Islam Nusantara, 03(02), 339-356.

Wibowo, Ari. (2020). Dakwah Berbasis Media dan Komunikasi Visual. Jurnal Bimbingan Penyuluhan Islam, 02(02), 183-199.

Zain, M. I. H. (2018). Kontekstualisasi Hadis Larangan Menggambar Dengan Desain Grafis. Riwayah : Jurnal Studi Hadis, 4(1), 101. https://doi.org/10.21043/riwayah.v4i1.2843

Zhang, L. (2018). Design and Research on Visual Communication under the Influence of Digital Media. In 6th International Conference on Social Science, Education and Humanities Research (pp. 257-260). 